\title{
Roles of Board of Directors in Organizational Ambidexterity
}

\author{
Jaeyoung Kang ${ }^{1}$ \\ ${ }^{1}$ Hagan School of Business, Iona College, United States \\ Correspondence: Jaeyoung Kang, Hagan School of Business, Iona College, 715 North Avenue, New Rochelle, NY, \\ 10801, United States. E-mail: jkang@iona.edu
}

Received: October 2, 2014

Accepted: October 22, 2014

Online Published: October 30, 2014

doi:10.5430/jms.v5n4p99

URL: http://dx.doi.org/10.5430/jms.v5n4p99

\begin{abstract}
Organization theory scholars have identified diverse antecedents to organizational ambidexterity including structure, context, and leadership characteristics. Each antecedent has been conceptualized as an alternative solution to organizational ambidexterity. This study argues that these distinct antecedents can have complementary effects on organizational ambidexterity. Differentiation mechanisms can generate new ideas, which are necessary for change and adaptation. Integration mechanisms make it possible to reconcile and address trade-offs and contradictions to achieve organizational ambidexterity. The aim of this research is to examine the interaction effect of these two distinct mechanisms on organizational ambidexterity in restaurant chain industry. Drawing on franchising and corporate governance literature, this paper proposes that the adoption of the franchising system can work as a differentiation mechanism and board of directors can be an integration mechanism. The results show when the number of outside directors and the average tenure of directors are combined with the adoption of the franchising system, chain performance increases.
\end{abstract}

Keywords: organizational ambidexterity, franchising, board of directors

\section{Introduction}

In recent years, there has been a growing interest in organizational ambidexterity (Birkinshaw \& Gupta, 2013). Organizational ambidexterity is defined as an organization's ability to simultaneously balance different activities in a trade-off situation (Rothaermel \& Alexandre, 2009). A recent meta-analysis showed that organizational ambidexterity is positively related to organizational performance at a business unit, firm, and inter-firm level (Junni, Sarala, Taras, \& Tarba, 2013). Empirical research showed that organizational ambidexterity has a positive effect on sales growth, subjective rating of performance, innovation, market valuation, and firm survival (O'Reilly \& Tushman, 2013). The main argument of organizational ambidexterity is that an organization's ability to reconcile and harness the conflicting demands can improve both short-term and long-term performances of the organization (Rothaermel \& Alexandre, 2009). Of particular interest to researchers has been how organizations can be ambidextrous. Previous research has extended our understanding of this topic through identifying antecedents that make it possible for organizations to develop the capabilities to address conflicting demands such as exploitation and exploration. Researchers have proposed structure, context, and leadership characteristics as antecedents of organization ambidexterity (O’Reilly \& Tushman, 2013; Raisch \& Birkinshaw 2008).

These diverse antecedents can be classified into differentiation and integration mechanisms (Raisch, Birkinshaw, Probst, \& Tushman, 2009). Differentiation antecedents enable organizations to develop different capabilities. The structural antecedent is an example of the differentiation mechanism. Explorative activities and exploitative activities are pursued in separate organization units which are specialized in each activity (Raisch et al., 2009). This differentiation mechanism helps organizations to develop capabilities which are different from current ones. On the other hand, integration antecedents enable organizations to address conflicting demands. The focus of integration mechanism is on development of conceptual connection among differentiated capabilities to identify potential synergies (Kogut \& Zander, 1992). O'Reilly and Tushman (2004) argued that tight coordination at the top level management facilitates sharing of the resources across the new units and the traditional units. This cross-fertilization can increase the ambidexterity capabilities (O'Reilly \& Tushman, 2004). Top managers frequently encounter trade-off situations while they allocate scarce resources. The finding of creative solutions, which can address the trade-off situations, can make organizations ambidextrous (Smith \& Lewis, 2011). The integration capabilities of top managers are of help in generating new solutions to deal with seemingly incompatible organizational goals 
(Andriopoulos \& Lewis, 2011). Therefore, the quality of management is critical to the success of organizational ambidexterity (Birkinshaw \& Gupta, 2013).

Scholars argued while each mechanism can contribute to organizational ambidexterity, neither is sufficient for organizational ambidexterity (Raisch et al., 2009). Differentiation mechanism creates different competencies that address disparate requirements. However, the potentials of distinct capabilities cannot be realized without integration mechanism which is associated with the sustained attention to the potential synergies among them (Smith \& Tushman, 2005). Mere existence of exploitative and explorative capabilities cannot lead to organization success (Gilbert, 2006) because value is created with the recombination of distinct capabilities in a way to increase efficiency and adaptation to external environment (O’Reilly \& Tushman, 2008; Teece, 2007). Critic of integration mechanism argues that without the differentiation mechanism, individual's differentiation capabilities will be constrained due to the lack of diversity in experiences, values, knowledge, and information (Inkpen \& Tsang, 2005).

Although it was argued that the integration and differentiation mechanisms are complementary, not alternative, this idea has not been empirically examined (Raisch et al., 2009). This study aims to address this research gap. This paper proposes a differentiation mechanism and an integration mechanism, then empirically tests the complementary effects of these two mechanisms in restaurant chain industry.

This paper suggests the use of franchising system as a differentiation mechanism. Board of directors is suggested as an integration mechanism which aims to develop a better business strategy by integrating new ideas and suggestions into a current business model. With these two mechanisms, this study tests whether chain performance is increased with the use of both mechanisms. The effectiveness of a board of directors as an integration mechanism can be influenced by many factors. Drawing on corporate governance literature, this research examines how board composition can influence integration capabilities of the board.

\section{Theory and Hypothesis Development}

\subsection{Adoption of the Franchising System as a Differentiation Mechanism}

The chain system has been widely used as a way to expand business by entrepreneurs who developed a successful business system (Combs \& Ketchen, 2003; Huarng \& Yu, 2014). There are two types of units under chain systems. The company-owned units are owned by chain owners and are managed by their employees (Murray \& Evans, 2013). The other type of unit is the franchised unit, which is operated by franchisees who purchase the right to market goods or services from chain owners and use the chain's business practices to make their own profits (Combs, Michael, \& Castrogiovanni, 2004).

This paper suggests that the adoption of the franchising system can allow chains to develop new ideas which help them to be more in tune with their environments. Chains should be able to adapt to new opportunities and threats to ensure sustainability over time (Bradach, 1997). The adoption of the franchising system can facilitate the adaptation of the chains which refers to the adaptation to macro environment changes to enhance their sustainability (Bürkle \& Posselt, 2008). Franchised units can work as a mechanism that promotes chain-wide changes of organization routines to adapt to environmental change (Méndez, Galindo, \& Sastre, 2014). Franchisees who receive residual claims have high-powered incentives to create and experiment with new ideas in order to enhance the adaptation to their environmental changes (Dada, Watson, \& Kirby, 2012). Thus, the franchising system can be used as a differentiation mechanism that limits organizational inertia and promotes new innovations and changes for chain-wide adaptations. Based on this argument, this paper hypothesizes that chains that adopt the franchising system will show higher performance than ones that do not.

\section{Hypothesis 1: The adoption of the franchising system will have a positive effect on chai performance.}

\subsection{Board of Directors as an Integration Mechanism}

Integration mechanism is required to fully take advantage of distinct capabilities provided by the franchising system (Jansen, Tempelaar, van den Bosch, \& Volberda, 2009). Bradach (1997), through his field study, found that many franchisees are willing to suggest new ideas to meet current and emerging customer needs. Without a proper integration mechanism, chains cannot incorporate new ideas into their business system. This paper proposes board of directors as an integration mechanism which helps organizations to balance external forces for innovation and change, and internal forces for efficiency. The role of integration mechanism is to look for ways that reconcile trade-offs generated by differentiation mechanisms (Smith \& Tushman, 2005). Development of conceptual connections among differentiated dimensions or products is critical to the integration mechanism (Dane, 2010; Suedfeld, Tetlock, \& Streufert, 1992). 
Boards of directors can work as an integration mechanism by participating in major strategic decisions. Although the most important role of the directors is to monitor managers to mitigate agency conflicts between managers and shareholders (Fama \& Jesen, 1983), they also provide resources including expertise, advice, and guidance so that the organization can make better strategic choices (Boyd, 1990; Daily \& Dalton, 1994; Goodstein, Gautam, \& Boeker, 1994; Pfeffer \& Salancik, 1978; Shropshire, 2010). The advice, information, and guidance available through the directors can at least partially influence strategic decisions of an organization (Westphal \& Fredrickson, 2001).

This paper draws upon human and social capital theory to examine how the composition of a board of directors can enhance the integration capabilities of an organization. Human capital is defined as an individual's knowledge, skills, and abilities typically developed through education, training, and various experiences (Becker, 1964; Coleman, 1988). Social capital can be defined as a sum of actual and potential resources that are available through a person's relationships with others (Nahapiet \& Ghoshal, 1998). The human and social capitals that directors bring to an organization can influence strategic decisions of the organization (Carpenter \& Westphal, 2001; Jensen \& Zajac, 2004).

\subsubsection{Number of Outside Directors}

The human capital of an organization can be enhanced by appointing outside directors (Bailey \& Helfat, 2003; Carpenter \& Westphal, 2001). Outside directors have distinct experiences in different fields. As the number of outside directors increases, they can bring more diverse perspectives, experience, knowledge, and skills which will increase the likelihood of connecting different ideas and identifying possible synergies (Burt, 1992).

Social capital provided by outside directors can contribute to the development of the integration capabilities of the board. Outside directors can provide more social capital since individuals who are separate from each other can have a distinct network of relationships (Burt, 1992). Directors can, through inter-organizational connections, facilitate the communication and exchange of information across organizations (Hillman \& Danizel, 2003). The timely and valuable information obtained through outside director's social capital can help organizations to develop better strategies to deal with challenges the environment poses (Hillman \& Danizel, 2003).

Thus, with the human capital and social capital available through outside directors, boards of directors that are composed of more outside directors can improve their ability to integrate different ideas and find solutions to balancing trade-offs developed by a differentiation mechanism. Based on this argument, it is hypothesized that the board of directors that is composed of more outside directors can develop a superior integration mechanism. When combined with a differentiation mechanism, it can increase chain performance.

Hypothesis 2: The number of outside directors moderates the relationship between the adoption of the franchising system and chain performance. As the number of outside directors increases in the board, the adoption of the franchising system has a positive effect on chain performance.

\subsubsection{Average Tenure of Directors}

As the tenure of directors on the board increases, they can develop organization-specific human capital and internal social capital. Each organization is idiosyncratic in terms of their resources and capabilities (Penrose, 1959). A better understanding of strengths and weaknesses of an organization is required in order to develop better strategies the organization can implement (Kor \& Mahoney, 2000). While working on a board, directors deepen their understanding of the resources and capabilities possessed by the organization. Fiske and Taylor (1991) argued that more experiences in an organization help individuals to access a richer stock of remembered information. With the development of organization-specific knowledge, outside directors can provide better suggestions and advice which help organizations to select a better strategy (Kor \& Sundaramurthy, 2009; Nahapiet \& Ghoshal, 1998).

With longer tenure, directors can develop internal social capital (Fischer \& Pollock, 2004). Directors can develop richer relationships with other directors and executives in the organization through the interactions with one another. These interactions increase familiarity among directors and help to develop mutual understanding of one another's personalities and behavioral styles as well as their skills and expertise (Fischer \& Pollock, 2004). This understanding can facilitate collaboration among them and make the decision making process smoother, which leads to the integration of ideas that help organizations select better strategies (Datta, 2011; Westphal \& Bednar, 2005).

Some scholars found that increased tenure is related to the greater rigidity and less changes (Musteen, Barker, \& Baeten, 2006). Boeker (1997) showed that the tenure of top management team is negatively related to strategic changes. People have a tendency to be reluctant to change once they have got used to a new environment (Staw, 1976).The negative effect of a longer tenure can be mitigated by a differentiation mechanism which provides new ideas and suggestions for the directors. Thus, the longer tenure on board can enhance the integration capabilities with 
the better understanding of the organization and people in the organization. When combined with a differentiation mechanism, it will lead to high performance.

Hypothesis 3: Director's average board tenure moderates the relationship between the adoption of the franchising and chain performance. As the average tenure of directors increases, the adoption of the franchising system has a positive effect on chain performance.

\subsubsection{Diversity of Tenure on the Board}

Although an individual's greater tenure on a board can increase an understanding of the organization and people in it, shared tenure among directors can have an adverse effect on the quality of decision making by the board of directors (Kor, 2006; Kor \& Mahoney, 2000). Shared tenure is the length of time that members of an organization stay together. This shared tenure can influence group decision making (Katz, 1982). The greater shared tenure on an organization's board can create shared frames of reference (Wiersema \& Bantel, 1992). This shared tenure increases the homogeneity of perspectives among members due to the common beliefs, understanding, and norm which have been developed through the same past experiences (Michel \& Hambrick, 1992). The increased familiarity can produce groupthink tendencies (Janis, 1972). Groupthink can decrease the quality of group decision making because people in a cohesive group tend to pursue unanimity instead of debating and questioning each other (Janis, 1972). Group members who show groupthink tendencies would not suggest diverse ideas (Forbes \& Milliken, 1999; Hambrick, 1995).

Maintaining heterogeneous perspectives can reduce this negative effect. Diversity in terms of board tenure can imply a broad set of perspectives on the opportunities and threats in the market and ideas and strategies an organization can use (Sawyer, Houlette, \& Yeagley, 2006). Diversity in tenure is related to diversity in cognitive frameworks which can improve the quality of discussion (Awino, 2013; Elenkov, Judge, \& Wright, 2005). While older tenured members can provide a solid understanding of the organization, newer members are able to provide different perspectives on the organization's future direction. Thus, this study proposes that having board members with diverse tenure can increase integration capabilities of the board. When the diversity of tenure ob the board is combined with a differentiation mechanism, it can increase chain performance.

Hypothesis 4: Diversity of tenure on the board moderates the relationship between the adoption of the franchising system and chain performance. As the board tenure diversity increases, the adoption of the franchising system has a positive effect on chain performance.

\section{Methods}

\subsection{Sample}

This paper tested the hypotheses with the data from publicly-traded restaurant chains. North American Industry Classification System (NAICS) was used to identify restaurant chains. Companies under NAICS code 722110 full-service restaurants) and 722211 (limited service restaurants) were included in the sample. Companies whose sales mainly come from a different industry were excluded. The dataset includes a total of 68 chain companies. I collected longitudinal data from 2004 to 2008. The number of observations used for data analysis was 264 . Financial information was collected from the Standard and Poor's COMPUSTAT database which is widely used to gather financial data. Data on board of directors was collected from proxy statements, and 10Ks of the chain.

\subsection{Variables}

\subsubsection{Dependent Variable}

Sales growth: The dependent variable in this study is sales growth of chains. Yin and Zajac (2004) found that sales growth is a highly relevant performance measure in the restaurant industry. This was measured by the percent changes in the chain-level sales from the previous year to the current year.

\subsubsection{Independent Variables}

Adoption of the franchising system: This research suggests the adoption of the franchising system as a differentiation mechanism. With the information provided by each chain's $10 \mathrm{ks}$, I could identify the chains which adopted the franchising system.

Number of outside directors: The number of directors who do not take managerial position in the organization was counted. Considering the purpose of this study, I did not exclude outside directors who have a relationship with the organization through business relationship or financing because this variable is not to measure the degree of independence of the board but to measure the amount of human and social capital that the outside directors provide 
(Daily, Johnson, \& Dalton, 1999). This study used the number of outside director rather than proportion of the outside directors because the number of outside directors can more accurately measure the amount of human and social capital offered by the outside directors.

Average tenure of directors: Following previous research (Fischer \& Pollock, 2004; Kor \& Sundaramurthy, 2009), directors' average number of years of service on the board in the current organization was used to measure organization-specific human and social capital.

Diversity of board tenure: The diversity board tenure was measured using coefficient of variation. Allison (1979) suggested the coefficient of variance because the coefficient of variation has scale invariant property. The coefficient in of variation was calculated by standard deviation divided by the mean of the tenure.

\subsubsection{Control Variables}

Previous year's sales: This paper uses sales growth as a dependent variable. The sales growth amount is expected to be influenced by total sales amount of the previous year. It is expected that the companies with a large amount of previous sales will have a smaller amount of sales growth.

Organization size: Organization size can influence sales growth. The franchising literature has used the number of total units to measure organization size (Alon, 2001; Falbe, Dandridge, \& Kumar, 1999; Lafontaine, 1992; Shane, Shankar, \& Aravindakshan, 2006).

Organization age: Organization theorists argued that organization age can influence its growth (Barron, West, \& Hannan, 1994). Organization age is measured as the number of years since the organization's establishment. This information was collected from annual reports, $10 \mathrm{Ks}$, or chain websites.

Service type: The restaurant's service type was also included as a control variable. The sample of this study was selected from two types of restaurants; full service restaurant and limited service restaurant. The service type was controlled with a dummy variable.

Table 1. Descriptive statistics and correlations

\begin{tabular}{|c|c|c|c|c|c|c|c|c|c|c|}
\hline & Mean & SD & 1 & 2 & 3 & 4 & 5 & 6 & 7 & 8 \\
\hline 1. Sales growth & 10.51 & 20.74 & & & & & & & & \\
\hline 2. Previous sales ${ }^{\mathrm{a}}$ & 5.94 & $1.63-$ & -0.04 & & & & & & & \\
\hline 3. Chain age & 35.13 & $18.97-$ & -0.10 & $0.22 * *$ & & & & & & \\
\hline 4. Chain size ${ }^{a}$ & 5.90 & $1.91-$ & -0.00 & $0.77^{* *}$ & $0.39 * *$ & & & & & \\
\hline 5. Full service & 0.74 & 0.44 & 0.04 & $-0.26 * *$ & $-0.27^{* *}$ & $-0.47 * *$ & & & & \\
\hline 6. Franchising system & 0.79 & $0.41-$ & -0.01 & $0.13 *$ & $0.30 * *$ & $0.44 * *$ & $*-0.22 * *$ & & & \\
\hline 7. Num of outsider director ${ }^{b}$ & 2.44 & 0.39 & 0.00 & $0.53 * *$ & $0.28 * *$ & $0.64 * *$ & $*-0.24 * *$ & $0.32 * *$ & & \\
\hline 8. Board average tenure ${ }^{\mathrm{b}}$ & 2.71 & 0.70 & 0.02 & $0.16 * *$ & $0.30 * *$ & 0.09 & -0.04 & 0.02 & -0.03 & \\
\hline 9. Board tenure diversity & 0.64 & $0.22-$ & -0.07 & $0.17 * *$ & 0.02 & 0.15 & $-0.16 *$ & $0.18^{* *}$ & $0.31^{* *}$ & -0.01 \\
\hline
\end{tabular}

\subsection{Analysis}

Estimation model: This dataset has panel structure because I collected data from 68 chains in the restaurant industry over 5 years. Fixed effects model is commonly used to test hypotheses with the panel data (Greene, 2003). The fixed effects model is preferred because it can parcel out the effects of unobserved organization-specific factors (Griliches 1986). Statistical assumptions were checked before testing hypotheses. Variables such as previous year's sales, the total number of units, the number of outside boarders, and the average tenure of directors are negatively skewed. These variables were transformed to have symmetric distributions. Multicollinearity problems were minimized with the inclusion of mean-centered interaction terms (Cohen, Cohen, West, \& Aiken, 2003). Because this data has panel structure, it is necessary to check whether there are organization-specific (chain) and time-specific (year) effects. A comparison of the two ordinary least-square models, one of which includes dummy variables and the other of which does not include dummy variables, was used to see whether chain-specific or year-specific effects on chain performance. The results showed that there were chain-specific effects but were not year-specific effects. Thus, the 
chain dummy variables were included to control for the chain-specific effects. Next, heteroskedasticity assumption was checked with Breusch-Pagan, Cook-Weisberg test. The result of this test indicated that the variance is not constant across chains (chi-square $(1)=173.47, p<.000$ ). The xtpcse model command Stata provides can fix this heteroskedasticity problem (Worrall \& Pratt, 2004). Last, panel data can have an autocorrelation problem. This problem occurs when the value of the previous year influences the value of the current year. Durbin-Watson statistic showed that this model has an autocorrelation problem since this statistics $(0.826445)$ is far from 2 . To fix the problem, previous sales variable was included in the estimation model. To consider lagged effects of the independent variables on chain performance, the independent variables measured at year $t$ were regressed on chain performance measured at year $t+1$.

Table 2. Results of fixed effect regression model: Influence on sales growth of chain

\begin{tabular}{|c|c|c|c|c|}
\hline Variables & Model 1 & Model 2 & Model 3 & Model 4 \\
\hline & Control & Franchising & $\begin{array}{l}\text { BOD main } \\
\text { effects }\end{array}$ & $\begin{array}{c}\text { Interaction } \\
\text { effects }\end{array}$ \\
\hline Constant & $-251.25 *$ & -61.42 & $-47.25 * * *$ & $45.06^{*}$ \\
\hline Firm dummy & Included & Included & Included & Included \\
\hline Previous sales & $-62.45 * * *$ & $-63.21 * * *$ & $-66.17 * * *$ & $-67.58 * * *$ \\
\hline Chain age & 1.12 & 1.04 & 0.85 & 1.64 \\
\hline Chain size & $72.74 * * *$ & $76.12 * * *$ & $78 . .85 * * *$ & $79.73^{* * *}$ \\
\hline Full service & 198.35 & 109.17 & 100.29 & 160.13 \\
\hline Franchising system $(\mathrm{H} 1)$ & & -11.39 & -10.46 & -19.57 \\
\hline $\mathrm{N}$ of outside director & & & 2.50 & -10.77 \\
\hline Board average tenure & & & $3 ; 31$ & 2.48 \\
\hline Board tenure diversity & & & $20.91 * *$ & 10.46 \\
\hline Franchising $\times \mathrm{N}$ of outside director $(\mathrm{H} 2)$ & & & & 27.16* \\
\hline Franchising $\times$ Board average tenure $(\mathrm{H} 3)$ & & & & 14.90* \\
\hline Franchising $\times$ Board tenure diversity $(\mathrm{H} 4)$ & & & & 15.03 \\
\hline Wald Chi squire $\left(\chi^{2}\right)$ & $354361.31 * * *$ & $18241.18^{* * *}$ & $4771.78 * * *$ & $4869.61 * * *$ \\
\hline $\mathrm{R}^{2}$ & 0.5753 & 0.5781 & 0.5995 & 0.6199 \\
\hline
\end{tabular}

\section{Results}

Table 1 displays means, standard deviations, and correlations for all variables used for this study. Table 2 reports the results of hypothesis tests. This study used the fixed effect model with sales growth as a dependent variable. Model 1 reports the results with control variables. The franchising system variable was included to model 2 to test hypothesis 1. Hypothesis 1 predicts that the adoption of the franchising system will increase chain performance measured by sales growth. The result in model 2 shows the coefficient of the franchising system variable is not statistically significant. Thus, hypothesis 1 was not supported. Model 4 tests the interaction effects of the franchising system and board composition. The interaction terms between the franchising system and board composition variables were added to model 4 . This model examines the complementary effects of the differentiation and integration mechanisms on chain performance. Hypothesis 2 predicts that the adoption of the franchising system will have a positive effect on chain performance as the number of outside directors increases. The interaction term between the franchising system and the number of outside director is positive and statistically significant. $(\beta=27.16, p<.05)$. The results provide supporting evidence for Hypothesis 2 . Hypothesis 3 predicts that the adoption of the franchising system will have a positive effect on chain performance as the average board tenure increases. The interaction term between the franchising system and average board tenure is positive and statistically significant $(\beta=14.90, p<.05)$. This finding supports hypothesis 3 . Hypothesis 4 concerns the interaction effect of the franchising system and board tenure diversity. The result in model 4 shows that the interaction term between the franchising system and board tenure diversity is not statistically significant. This result does not support hypothesis 4 . 


\section{Discussion}

This study investigated how organizations can enhance organization ambidexterity. Although it has been suggested that both differentiation and integration mechanisms are required for organizational ambidexterity (Raisch, et al., 2009), little research has examined the complementary effects of the two mechanisms. Differentiation mechanism is required to create distinct capabilities to enhance adaptation to new environments. Integration mechanism enables organizations to combine distinct capabilities in a way to create synergies by addressing conflicting demands (Smith \& Tushman, 2005).

In this paper, I suggested the adoption of the franchising system as a differentiation mechanism in restaurant chain industry. Franchisees who are the owners of their units are more motivated to search new opportunities and suggest new ideas to meet their customer's changing needs (Bradach, 1997). This paper proposed board of directors as an integration mechanism. With the diverse human and social capital provided by board of directors, organizations can enhance integration capabilities to create connections among distinct capabilities. In general, this study provided supporting evidence of the complementary effects of differentiation and integration mechanisms. Hypothesis 1 suggests that the adoption of the franchising system will enhance chain performance. This hypothesis tests whether a differentiation mechanism alone can contribute to chain performance. The hypothesis was not supported. It can imply that an exclusive use of the differentiation mechanism may not be sufficient to enhance organization ambidexterity (Raisch et al., 2009). Another possible explanation for this insignificant result is the use of a dummy variable to measure the differentiation mechanism. The ratio of franchised units varies widely among chains ranging from .01 to .99 . It is possible that too low or too high a proportion of franchised units may not enhance organization ambidexterity because of the lack of balance between exploitative and explorative activities.

Model 3 in Table 2 provides some insights into the research question examined in this paper. Model 3 includes three main effects of board composition characteristics. Model 3 shows that the main effects of the number of outside directors and average board tenure on chain performance are not statistically significant. As we see in Model 4, these two board composition characteristics lead to increase in chain performance only when they are combined with a differentiation mechanism. It may imply that these board composition characteristics are not sufficient for organizational ambidexterity. The results of the main effect and the interaction effect of board tenure diversity provide interesting insights. Model 3 in Table 2 shows that the main effect of board tenure diversity has a positive effect on chain performance. However, the interaction term between the adoption of the franchising system and board tenure diversity is not statistically significant. It means that the use of the franchising system does not contribute to the increase in chain performance when boards are composed of directors with a diverse set of tenures. In other words, board tenure diversity can be a sufficient factor that leads to the growth of chain performance. It implies that some characteristics represented by board tenure diversity can enhance differentiation and integration capabilities simultaneously. Smith and Tushman (2005) suggested that top management teams' cognitive process and behavioral interactions can be antecedents of both differentiation and integration capabilities for organizational ambidexterity. This could be possible when directors with shorter tenure can work as a differentiation mechanism by suggesting new ideas and challenging organizational norms and directors with longer tenure may have better ideas of how to integrate the new ideas suggested by new directors into the organization. Further research would be required to test this potential explanation.

This research contributes to the organizational ambidexterity literature in several ways. First I provided empirical evidence that shows the complementary effect of differentiation and integration mechanisms for organizational ambidexterity. While previous research focused on either differentiation or integration mechanism of organizational ambidexterity, this paper incorporated two mechanisms and showed that the benefits of each mechanism can be enhanced with the other mechanism. This research suggests that human and social capital provided by directors can contribute to the development of superior integration capabilities.

This research has several limitations that should be noted. First, I used board composition as a proxy to measure integration capabilities. Although demographic characteristics and experiences can serve as proxies for cognitive framework (Carpenter, Geletkanycz, \& Sanders, 2004), they do not accurately measure the internal cognitive process of directors. Researchers can use a field study or survey for more accurate measurements of cognitive processes of boards of directors to provide in-depth insights into this issue. This research drew the sample from only one industry. Although single-industry design can control potential industry effects (Roquebert, Phillips, \& Westfall, 1996), caution should be used in generalizing beyond the restaurant industry. Future research can test whether the findings of this research can be generalizable to other industries. 


\section{References}

Allison, P. D. (1978). Measures of inequality. American Sociological Review, 43, 865-880.

Alon, I. (2001). The use of franchising by U.S.-based retailers. Journal of Small Business Management, 39, 111-122. http://dx.doi.org/10.1111/1540-627X.00011

Andriopoulos, C., \& Lewis, M. W. (2010). Managing innovation paradoxes: Ambidexterity lessons from leading product design companies. Long Range Planning, 43, 104-122. http://dx.doi.org/10.1016/j.lrp.2009.08.003

Awino, Z. B. (2013). Top management team diversity, quality decisions and organizational performance in the service industry. Journal of Management and Strategy, 4, 113-123. http://dx.doi.org/10.5430/jms.v4n1p113

Bailey, E. E., \& Helfat, C. E. (2003). External management succession, human capital, and firm performance: An integrative analysis. Managerial and Decision Economics, 24, 347-369. http://dx.doi.org/10.1002/mde.1119

Barron, D., West, E., \& Hannan, M. (1994). A time to grow and a time to die: Growth and mortality of credit unions in New York City, 1914-1990. American Journal of Sociology, 100, 381-421. http://dx.doi.org/10.1086/230541

Becker, G. S. (1964). Human capital: A theoretical and empirical analysis, with special reference to education. New York, NY: National Bureau of Economic Research \& Columbia University Press.

Birkinshaw, J. M., \& Gupta, K. (2013). Clarifying the distinctive contribution of ambidexterity to the field of organization studies. Academy of Management Perspectives, 27, 287-298. http://dx.doi.org/ 10.5465/amp.2012.0167

Boeker, W. (1997). Executive migration and strategic change: The effect of top manager movement on product market entry. Administrative Science Quarterly, 47, 92-124. http://dx.doi.org/10.2307/2393919

Boyd, B. (1990). Corporate linkages and organizational environment: A test of the resource dependence model. Strategic Management Journal, 11, 419-430. http://dx.doi.org/10.1002/smj.4250110602

Bradach, J. L. (1997). Using the plural form in the management of restaurant chains. Administrative Science Quarterly, 42, 276-303. http://dx.doi.org/10.2307/2393921

Bürkle, T., \& Posselt, T. (2008). Franchising as a plural system: A risk-based explanation. Journal of Retailing, 84, 39-47. http://dx.doi.org/10.1016/j.jretai.2008.01.004

Burt, R. S. (1992). Structural holes. Cambridge, MA: Harvard University Press.

Carpenter, M. A., Geletkanycz, M. A., \& Sanders, W. G. (2004). Upper echelons research revisited: Antecedents, elements, and consequences of top management team composition. Journal of Management, 30, 749-778. http://dx.doi.org/10.1016/j.jm.2004.06.001

Carpenter, M. A., \& Westphal, J. D. (2001). The strategic context of external network ties: Examining the impact of director appointments on board involvement in strategic decision making. Academy of Management Journal, 44, 639-660. http://dx.doi.org/10.2307/3069408

Cohen, J., Cohen, P., West, S. G., \& Aiken, L. S. (2003). Applied multiple regression/correlation analysis for the behavioral sciences (3rd ed.). Mahwah, NJ: Erlbaum.

Coleman, J. S. (1988). Social capital in the creation of human capital. American Journal of Sociology, 94, S95-S120 http://dx.doi.org/10.1002/job.1853

Combs, J. G., \& Ketchen, D. J. (2003). Why do firms use franchising as an entrepreneurial strategy?: A meta-analysis. Journal of Management, 29, 443-465. http://dx.doi.org/10.1016/S0149-2063(03)00019-9

Combs, J. G., Michael, S. C., \& Castrogiovanni, G. J. (2004). Franchising: A review and avenues to greater theoretical diversity. Journal of Management, 30, 907-932. http://dx.doi.org/10. 1016/j.jm.2004.06.006

Dada, O., Watson, A., \& Kirby, D. (2012). Toward a model of franchisee entrepreneurship. International Small Business Journal, 30, 559-583. http://dx.doi.org/10.1177/0266242610376078

Daily, C., \& Dalton, D. (1994). Bankruptcy and corporate governance: The impact of board composition and structure. Academy of Management Journal, 37, 1603-1617. http://dx.doi.org/10.2307/256801

Daily, C. M., Johnson, J. L., \& Dalton, D. R. (1999). On the measurement of board composition: Poor consistency and a serious mismatch of theory and operationalization. Decision Sciences, 30, 83-106. http://dx.doi.org/10.1111/j.1540-5915.1999.tb01602.x 
Dane, E. (2010). Reconsidering the trade-off between expertise and flexibility: A cognitive entrenchment perspective. Academy of Management Review, 35, 579-603. http://dx.doi.org/10.5465/AMR.2010.53502832

Datta, A. (2011). Review and extension on ambidexterity: A theoretical model integrating networks and absorptive capacity. Journal of Management and Strategy, 2, 1-22. http://dx.doi.org/doi:10.5430/jms.v2n1p2

Elenkov, D. S., Judge, W., \& Wright, P. (2005). Strategic leadership and executive innovation influence: An international multi-cluster comparative study. Strategic Management Journal, 26, 665-682. http://dx.doi.org/10.1002/smj.469

Falbe, C. M., Dandridge, T. C., \& Kumar, A. (1999). The effect of organizational context on entrepreneurial strategies in franchising. Journal of Business Venturing, 14, 125-140. http://dx.doi.org/10.1016/S0883-9026(97)00099-2

Fama, E. F., \& Jensen, M. C. (1983). Separation of ownership and control. Journal of Law and Economics, 26, 301-325.

Fischer, H. M., \& Pollock, T. G. (2004). Effects of social capital and power on surviving transformational change: The case of initial public offerings. Academy of Management Journal, 47, 463-481. http://dx.doi.org/10.2307/20159597

Fiske, S. T., \& Taylor, S. E. (1991). Social Cognition (2nd ed.). New York, NY: McGraw-Hill.

Forbes, D. P., \& Milliken, F. J. (1999). Cognition and corporate governance: Understanding board of directors as strategic decision-making groups. Academy of Management Review, 24, 489-505. http://dx.doi.org/10.5465/AMR.1999.2202133

Gilbert, C. G. (2006). Change in the presence of residual fit: Can competing frames coexist? Organization Science, 17, 150-167. http://dx.doi.org/10.1287/orsc. 1050.0160

Goodstein, J., Gautam, K., \& Boeker, W. (1994). The effects of board size and diversity on strategic change. Strategic Management Journal, 15, 241-250. http://dx.doi.org/10.1002/smj.4250150305

Greene, W. H. (2003). Econometric analysis (5th ed.). Upper Saddle River, NJ: Prentice Hall.

Griliches, Z. (1986). Data problems in econometrics. In M. Intriligator \& Z. Griliches (Eds.), Handbook of econometrics (pp. 1466-1514). Amsterdam: North-Holland.

Hambrick, D. C. (1995). Fragmentation and the other problems CEOs have with their top management teams. California Management Review, 37, 110-127.

Hillman, A. J., \& Dalziel, T. (2003). Boards of directors and firm performance: Integrating agency and resource dependence perspectives. Academy of Management Review, 28, 383-396. http://dx.doi.org/10.5465/AMR.2003.10196729

Huarng, K., \& Yu, T. H. (2014). Analysis of franchisors' expansion strategies and competition. Service Industries Journal, 34, 856-866. http://dx.doi.org/10.1080/02642069.2014.905918

Inkpen, A. C., \& Tsang, E. W. K. (2005). Social capital, networks, and knowledge transfer. Academy of Management Review, 30, 146-165. http://dx.doi.org/10.5465/AMR.2005.15281445

Janis, I. L. (1972). Victims of groupthink: A psychological study of foreign-policy decisions and fiascoes. Boston, MA: Houghton Mifflin.

Jansen, J. J. P., Tempelaar, M. P., van den Bosch, F. A. J., \& Volberda, H. W. (2009). Structural differentiation and ambidexterity: The mediating role of integration mechanisms. Organization Science, 20, 797-811. http://dx.doi.org/10.1287/orsc.1080.0415

Jensen, M., \& Zajac, E. J. (2004). Corporate elites and corporate strategy: How demographic preferences and structural position shape the scope of the firm. Strategic Management Journal, 25, 507-524. http://dx.doi.org/10.1002/smj.393

Junni, P., Sarala, R. M., Taras, V., \& Tarba, S.Y. (2013). Organizational ambidexterity and performance: A meta-analysis. Academy of Management Perspectives, 27, 299-312. http://dx.doi.org/ 10.5465/amp.2012.0015

Katz, R. (1982). The effects of group longevity on project communication and performance. Administrative Science Quarterly, 27, 81-104. http://dx.doi.org/10.2307/2392547 
Kogut, B., \& Zander, U. (1992). Knowledge of the firm, combinative capabilities, and the replication of technology. Organization Science, 3, 383-397. http://dx.doi.org/10.1287/orsc.3.3.383

Kor, Y. Y. (2006). Direct and interaction effects of top management team and board composition on R\&D investment strategy. Strategic Management Journal, 27, 1081-1099. http://dx.doi.org/10.1002/smj.554

Kor, Y. Y., \& Mahoney, J. T. (2000). Penrose's resource-based approach: The process and product of research creativity. Journal of Management Studies, 37, 109-139. http://dx.doi.org/10.1111/1467-6486.00174

Kor, Y. Y., \& Sundaramurthy, C. (2009). Experience-based human capital and social capital of outside directors. Journal of Management, 35, 981-1006. http://dx.doi.org/10.2139/ssrn.1090251

Lafontaine, F. (1992). Agency theory and franchising: Some empirical results. RAND Journal of Economics, 23, 263-283. http://dx.doi.org/10.2307/2555988

Méndez, M. T., Galindo, M.-A., \& Sastre, M.-A. (2014). Franchise, innovation and entrepreneurship. Service Industries Journal, 34, 843-855. http://dx.doi.org/10.1080/02642069.2014.905926

Michel, J. G., \& Hambrick, D. C. (1992). Diversification posture and top management team characteristics. Academy of Management Journal, 35, 9-37. http://dx.doi.org/10.2307/256471

Murray, L. M., \& Evans, K. R. (2013). Store managers, profitability and satisfaction in multi-unit enterprises. Journal of Services Marketing, 27, 207-222. http://dx.doi.org/10.1108/08876041311330708

Musteen, M., Barker, V. L., \& Baeten, V. L. (2006). CEO attributes associated with attitude toward change: The direct and moderating effects of CEO tenure. Journal of Business Research, 59, 604-612. http://dx.doi.org/10.1016/j.jbusres.2011.09.024

Nahapiet, J., \& Ghoshal, S. (1998). Social capital, intellectual capital, and the organizational advantage. Academy of Management Review, 23, 242-266. http://dx.doi.org/10.5465/AMR.1998.533225

O’Reilly, C. A., \& Tushman, M. L. (2004). The ambidextrous organization. Harvard Business Review, 82, 74-81.

O'Reilly, C. A., \& Tushman, M. L. (2008). Ambidexterity as a dynamic capability: Resolving the innovator's dilemma. Research in Organization Behavior, 28, 185-206. http://dx.doi.org/10.1016/j.riob.2008.06.002

O'Reilly, C. A., \& Tushman, M. L. (2013). Organizational ambidexterity: Past, present, and future. Academy of Management Perspectives, 27, 324-338. http://dx.doi.org/10.5465/amp.2013.0025

Penrose, E. T. (1959). The theory of the growth of the firm. New York, NY: John Wiley.

Pfeffer. J., \& Salancik, G. (1978). The external control of organizations: A resource-dependence perspective. New York, NY: Harper \& Row.

Raisch, S., \& Birkinshaw, J. (2008). Organizational ambidexterity: Antecedents, outcomes, and moderators. Journal of Management, 34, 375-409. http://dx.doi.org/10.1177/0149206308316058

Raisch, S., Birkinshaw, J., Probst, G., \& Tushman, M. L. (2009). Organizational ambidexterity: Balancing exploitation and exploration for sustained performance. Organization Science, 20, 685-695. http://dx.doi.org/10.1287/orsc.1090.0428

Roquebert, J. A., Phillips, R. L., \& Westfall, P. A. (1996). Market vs. management: What drives profitability? Strategic Management Journal, http://dx.doi.org/10.1002/(SICI)1097-0266(199610)17:8<653::AID-SMJ840>3.0.CO;2-O

Rothaermel, F. T., \& Alexandre, M. T. (2009). Ambidexterity in technology sourcing: The moderating role of absorptive capacity. Organization Science, 20, 759-780. http://dx.doi.org/10.1287/orsc.1080.0404

Sawyer, J. E., Houlette, M. A., \& Yeagley, E. L. (2006). Decision performance and diversity structure: Comparing faultlines in convergent, crosscut, and racially homogeneous groups. Organizational Behavior and Human Decision Processes, 99, 1-15. http://dx.doi.org/10.1016/j.obhdp.2005.08.006

Shane, S. A., Shankar, V., \& Aravindakshan, A. (2006). The effects of new franchisor partnering strategies on franchise system size. Management Science, 52, 773-787. http://dx.doi.org/10.1287/mnsc.1050.0449

Shropshire, C. (2010). The role of the interlocking director and board receptivity in the diffusion of practices. Academy of Management Review, 35, 246-64. http://dx.doi.org/10.5465/AMR.2010.48463333

Smith, W. K., \& Lewis, M. W. (2011). Toward a theory of paradox: A dynamic equilibrium model of organizing. Academy of Management Review, 36, 381-403. http://dx.doi.org/10.5465/AMR.2011.59330958 
Smith, W. K., \& Tushman, M. L. (2005). Managing strategic contradictions: A top management model for managing innovation streams. Organization Science, 16, 522-536. http://dx.doi.org/10.1287/orsc.1050.0134.

Staw, R. M. (1976). Knee-deep in the big muddy: A study of escalating commitment to a chosen course of action. Organization Behavior and Human Performance, 16, 27-44. http://dx.doi.org/10.1016/0030-5073(76)90005-2

Suedfeld, P., Tetlock, P., \& Streufert, S. (1992). Conceptual/integrative complexity. In C. Smith, J. Atkinson, D. McClelland, \& J. Verof (Eds.), Motivation and Personality: Handbook of Thematic Content Analysis (pp. 393-400). Cambridge, England: Cambridge University Press.

Teece, D. J. (2007). Explicating dynamic capabilities: The nature and microfoundations of (sustainable) enterprise performance. Strategic Management Journal, 28, 1319-1350. http://dx.doi.org/10.1002/smj.640

Westphal, J. D., \& Bednar, M. K. (2005). Pluralistic ignorance in corporate boards and firms' strategic persistence in response to low firm performance. Administrative Science Quarterly, 50, 262-298. http://dx.doi.org/10.2189/asqu.2005.50.2.262

Westphal, J. D., \& Fredrickson, J. W. (2001). Who directs strategic change? Director experience, the selection of new CEOs, and change in corporate strategy. Strategic Management Journal, 22, 1113-1137. http://dx.doi.org/10.1002/smj.205

Wiersema, M. F., \& Bantel, K. A. (1992). Top management team demography and corporate strategic change. Academy of Management Journal, 35, 91-121. http://dx.doi.org/10.2307/256474

Worrall, J. L., \& Pratt, T. C. (2004). Estimation issues associated with time-series-cross-section analysis in criminology. Western Criminology Review, 5, 35-49.

Yin, X., \& Zajac, E. J. (2004). The strategy/governance structure fit relationship: Theory and evidence in franchising arrangements. Strategic Management Journal, 25, 365-383. http://dx.doi.org/10.1002/smj.389 